\title{
Efek perlakuan pack carburizing dan media korosif pada baja AISI 1045 terhadap laju korosi
}

\author{
( Ketut Suarsana ${ }^{1}{ }^{\star}$, I Made. Astika1), I Gede Putu Agus Suryawan'), \\ Dani Kurniawan ${ }^{1)}$ \\ 1) Jurusan Teknik Mesin Universitas Udayana, Kampus Bukit Jimbaran Bali
}

Naskah diterima 20/06/2021; direvisi 20/09/2021; disetujui 30/09/2021 doi: https://doi.org/10.24843/JEM.2021.v14.i02.p01

\begin{abstract}
Abstrak
Korosi merupakan suatu gejala destruktif yang mempengaruhi sifat logam, yaitu menurunnya sifat fisik dan mutu logam akibat reaksi elektrokimia antara logam dengan lingkungannya yang mengakibatkan kekuatan logam menjadi menurun. Untuk dapat menghindari dampak negatif dari korosi maka dilakukan pengendalian korosi salah satunya melalui melalui metode perlakuan pack carburizing. Bahan yang digunakan dalam penelitian adalah baja AISI 1045. Untuk mengetahui pengaruh pack carburizing terhadap tingkat laju korosi baja maka dilakukan dengan cara memvariasikan suhu pack carburizing dan media korosif. Pada penelitian ini proses pack carburizing dengan variasi suhu yang digunakan adalah $750^{\circ} \mathrm{C}, 850^{\circ} \mathrm{C}, 950^{\circ} \mathrm{C}$ dan media pengkorosi yang digunakan adalah udara, air tawar dan air laut. Hal ini diteliti sesuai dengan aplikasi penggunaan bahan AISI 1045. Proses pengkorosian dengan media korosif dilakukan selama 720 jam. Hasil penelitian menunjukkan bahwa baja yang dipack carburizing pada suhu $950^{\circ} \mathrm{C}$ memiliki tingkat laju korosi lebih rendah dibandingkan dengan baja yang dipack carburizing pada tempertur $750^{\circ} \mathrm{C}$. Begitu juga media korosif udara memberikan tingkat laju korosi lebih rendah dibandingkan dengan tingkat laju korosi air laut.
\end{abstract}

Kata kunci: Pack carburizing, media korosif, laju korosi

\section{Abstract}

Corrosion is a destructive symptom that affects the properties of a metal, which means that the physical properties and quality of the metal decrease due to the electrochemical reaction between the metal and its environment so that the strength of the metal decreases. Corrosion control can be used to avoid the negative impact of corrosion, through the pack carburizing treatment method. The material used in this research is AISI 1045 steel. To determine the effect of pack carburizing on the corrosion rate of steel, the research was carried out by varying the suhue of the carburizing pack and corrosive media. In this study, the pack carburizing process with suhue variations used was $750^{\circ} \mathrm{C}, 850^{\circ} \mathrm{C}$, $950^{\circ} \mathrm{C}$ and the corroding media used were air, fresh water and sea water. This was observed in accordance with the application of AISI 1045 material. The corrosive process through corrosive media was carried out for 720 hours. The results showed that pack carburized steel at a temperature of $950^{\circ} \mathrm{C}$ had a lower corrosion rate than pack carburized steel at $750^{\circ} \mathrm{C}$. Also, air corrosive media provides a lower corrosion rate compared to seawater corrosion rate.

Key words: Pack carburizing, corrosive media, corrosion rate

\section{Pendahuluan}

Banyak aktivitas yang dilakukan manusia terkait dengan pemanfaatan logam sebagai alat bantu mempermudah pekerjaan. Namun demikian banyak dijumpai material logam yang umur pemakaiannya lebih singkat dari yang ditentukan, salah satu penyebabnya adalah korosi. Korosi merupakan perusakan logam yang mempengaruhi mutu logam akibat dari reaksi kimia atau elektrokimia antara logam dengan lingkungan [1].

Dalam banyak hal korosi dapat dihindari dengan cara pemilihan bahan yang tepat dan perancangan yang baik dengan mempertimbangkan lingkungan dimana logam itu dipakai. Penggunaan material logam pada lingkungan korosif bisa menyebabkan logam rawan terkorosi, jika hal ini diabaikan maka sebagian unsur logam bisa hilang dan mengakibatkan material logam terjadi konsentrasi tegangan serta menjadikan sifat material logam menurun kekuatannya [2].

Dalam hal tentang penggunaan material logam dilingkungan korosif, yang bisa menyebabkan hilangnya sebagian unsur logam dan menjadikan material logam menurun kekuatannya, maka terjadi konsekuensi perlunya penelitian untuk mengatasi masalah tersebut. Dengan penelitian pengaruh pack carburizing terhadap laju korosi, dimana pada material tersebut ditambahkan unsur karbon pada permukaan, menjadikan perbedaan struktur mikro antara bagian permukaan dengan bagian dalam material logam, dan mengakibatkan pula perbedaan ketahanan terhadap korosi. Dengan perlakuan pack carburizing yang tepat diharapkan pada material logam mempunyai ketahanan yang baik terhadap lingkungan korosif, sehingga dapat

\footnotetext{
*Korespondensi: Tel.: +6281338606307

E-mail: kt.suarsana65@gmail.com
} 
menaikkan umur serta efisiensi pemakaian baja AISI 1045 [3].

Penelitian telah dilakukan untuk mencari solusi perlakuan panas yang tepat pada baja AISI 3115, maka diberikan perlakuan panas (heat treatment) dengan variasi suhu $750^{\circ} \mathrm{C}, 850^{\circ} \mathrm{C}$, $950^{\circ} \mathrm{C}$ dan pendinginan cepat menggunakan cairan berupa air dalam suatu wadah, yang diharapkan dapat meningkatkan kekerasan baja AISI 3115. Hasil penelitian dari proses karburasi yang diikuti perlakuan panas dan pendinginan cepat, serta penambahan bahan pengaktif kalsium karbonat dan batubara sub bituminous mempunyai pengaruh untuk meningkatkan kekerasan pada baja karbon rendah AISI 3115. Semakin tinggi temperatur heat treatmentmaka kekerasan semakin meningkat dan nilai tingkat karbon juga ikut meningkat berdasarkan parameter suhu yang tinggi, dikarenakan peningkatan nilai karbon pada baja menggunakan karbon berupa batubara subituminus dengan pengikat berupa calsium karbonat. Fungsi dari calsium karbonat juga sebagai media untuk mempercepat proses karburasi. Pengaruh temperatur terbaik terdapat pada suhu $950^{\circ} \mathrm{C}$ dengan nilai kekerasan tertinggi sebesar 38,14. sebaliknya memiliki laju korosi terlambat dengan nilai 2,86 mpy dan foto struktur mikro terbaik terdapat pada suhu $850^{\circ} \mathrm{C}$, dikarenakan ferrit yang bewarna terang pada baja menandakan bahwa baja bersifat tidak keras, sedangkan pearlit yang bewarna gelap bersifat keras karena titik hitam lebih banyak dibandingkan titik putih maka nilai kekerasan terbaik di dapat pada suhu $850^{\circ} \mathrm{C}$. [4].

Untuk melakukan proses pack carburizing, diperlukan sebuah tungku pembakar yang dirancang tahan panas serta mudah dioperasikan aman dengan bahan bakar batu bara untuk penguji tungku yang telah dirancang dilakukan pengujian pada baja kabon rendah dengan mengunakan media karburisasi campuran $500 \mathrm{gr}$ arang tempurung kelapa dan $50 \mathrm{gr}$ calsium carbonat $\left(\mathrm{CaCO}_{3}\right)$, temperatur pemanasan $950^{\circ} \mathrm{C}$ dan variasi waktu tahan; 3 jam 4 jam dan 5 jam. Kemudian dilanjukan dengan proses quenching. Dari hasil pengujian kekerasan di peroleh data kekerasan $34 \mathrm{Hrc}$ pada waktu tahan 5 jam. Ini menunjukan bahan uji telah terjadi pengerasan permukaan dengan bertambahnya unsur karbon pada permukaan bahan uji [5].

Penelitian menurut [6], korosi merupakan kerusakan atau penurunan mutu atau keausan material akibat reaksi dengan lingkungan yang didukung oleh faktor-faktor tertentu yang ada pada lingkungan pengunaan logam. Laju korosi tergantung pada faktor temperatur, konsentrasi reaktan, jumlah mula-mula partikel (massa) logam, dan faktor mekanik seperti tegangan [2]. Baja karbon merupakan material yang paling banyak dipakai dalam industri pengolahan gula karena mempunyai sifat-sifat yang relatif baik dan harga yang lebih terjangkau, tetapi mempunyai beberapa kelemahan diantaranya ketahanan korosinya yang relatif rendah. Baja karbon diklasifikasikan berdasarkan besarnya kandungan karbonnya menjadi 3 jenis yaitu baja karbon rendah, karbon sedang, dan karbon tinggi [7].

Menurut penelitian hasil uji polarisasi, laju korosi paling rendah terjadi pada material SS 304 dengan nilai $0,490 \mathrm{~mm} /$ year pada $\mathrm{pH}$ 5,88, sedangkan laju korosi palingtinggi terjadi pada material SS 430 dengan nilai $0,796 \mathrm{~mm} /$ year pada $\mathrm{pH} 5,88$. Laju korosi pada SS 304 dalam larutan nira tersebut termasuk dalam kategori rendah, sedangkan laju korosi pada material baja karbon rendah, SS 201 dan SS430 termasuk dalam kategori sedang [8].

Perusakan logam akibat reaksi kimia atau elektrokimia dengan lingkungannya disebut dengan korosi. Korosi yang berintraksi dengan lingkungannya diantaranya adalah Stress Corrosion yaitu korosi yang timbul sebagai akibat bekerjanya tegangan dan media korosif. Korosi menyebabkan terjadinya keretakan. tegangan yang bekerja pada material logam adalah tegangan tekan, dapat berupa tegangan sisa. Yang termasuk jenis korosi ini adalah season cracking pada kuningan, juga corrosion fatigue, yang menyebabkan turunnya fatigue strength karena adanya media yang korosif. Setelah proses deformasi akan mendapatkan perubahan bentuk struktur mikro yang mempunyai ketahanan yang lebih baik terhadap korosi pada lingkungan yang sama, sehingga dapat menaikkan umur lelah baja, mengurangi laju korosi serta efisiensi pemakaian [3].

Pada penelitian yang dilakukan ini menganalisis pengaruh perlakuan temperatur pack carburizing dan media korosif pada baja AISI 1045 untuk mengetahui perubahan laju korosi serta efisiensi. Media korosif digunakan adalah udara, air tawar dan air laut. Sedangkan untuk perlakuan tempertur pack carburizing $750^{\circ} \mathrm{C}, 850^{\circ} \mathrm{C}$ dan $950^{\circ} \mathrm{C}$. Penelitian ini menguji pengaruh temperatur pack carburizing dan media korosif terhadap laju korosi yang terjadi pada baja karbon. Metode pengkorosian dilakukan dengan merendam spesimen pada media korosif selama 720 jam (30 hari), setelah itu diukur perbedaan berat serta menghitung laju korosi. Penjelasan rinci tentang objek penelitian dan protokol eksperimental disajikan di bagian materi dan metode. Hasil pengukuran akan disajikan dan dianalisis pada bagian hasil dan pembahasan.

\section{Metode Penelitian}

\subsection{Bahan Penelitian}

Material uji yang digunakan baja AISI 1045 yang mempunyai komposisi kimia sebagai berikut: Carbon (C): 0,43 - 0,50\%; Mangan (Mn): 0,60 0,90\%; Phosfor (P): 0,040\% max; Sulfur (S): 
0,050\% max; Ferrum (Fe): 0,5 - 0,88\%. Untuk komposisi kimia bahan pengkarburasi: Arang kayu: $75 \% ; \mathrm{NaCO}_{3}: 22 \% ; \mathrm{CaCO}_{3}: 3 \%$. Sedangkan untuk media korosif yang digunakan: air tawar, air laut dan udara.

\subsection{Proses Pack Carburizing}

Pack Carburizing merupakan cara penambahan karbon yang menggunakan media padat sebagai media carburizing seperti $70-80 \%$ arang. Untuk mempercepat proses maka ditambahkan 2,5 - 3,5\% kalsium carbonat $\left(\mathrm{CaCO}_{3}\right)$ dan 20 - $25 \%$ natrium karbonat $\left(\mathrm{NaCO}_{3}\right)$. Selama proses pemanasan pack carburizing udara yang terperangkap akan bereaksi dengan arang menjadi karbon monoksida (CO), selanjutnya $\mathrm{CO}$ akan berdissosiasi menjadi karbon aktif (Cat). Dengan reaksi sebagai berikut:

$$
\begin{aligned}
& 2 \mathrm{C}+\mathrm{O}_{2}---2 \mathrm{CO} \\
& 2 \mathrm{CO}---\mathrm{CO}_{2}+\mathrm{Cat}
\end{aligned}
$$

Karbonat dari natrium karbonat $(\mathrm{NaCO} 3)$ dan kalsium karbonat $\left(\mathrm{CaCO}_{3}\right)$ berfungsi sebagai energizer mempercepat proses carburizing yaitu dengan banyak menghasilkan sejumlah $\mathrm{CO}_{2}$ dari reaksi:

$$
\begin{aligned}
& \mathrm{NaCO}_{3}+\text { panas --- } \mathrm{NaO}+\mathrm{CO}_{2} \\
& \mathrm{CaCO}_{3}+\text { panas --- } \mathrm{CaO}+\mathrm{CO}_{2}
\end{aligned}
$$

Selanjutnya gas karbon dioksida $\left(\mathrm{CO}_{2}\right)$ bereaksi dengan karbon dari arang kayu membentuk karbon monoksida (CO), dimana CO ini dapat bereaksi berdissosiasi menjadi karbon aktif (Cat). Dengan reaksi sebagai berikut:

$$
\begin{aligned}
& \mathrm{CO}_{2}+\mathrm{C}----2 \mathrm{CO} \\
& 2 \mathrm{CO}----\mathrm{CO}_{2}+\mathrm{Cat}
\end{aligned}
$$

Karbon aktif (Cat) inilah yang akan larut atau berdifusi kedalam permukaan baja [9].

\subsection{Media Korosif}

Korosi adalah penurunan mutu logam karena reaksi elektrokimia antara logam dengan lingkungan. Adapun lingkungan yang dimaksud dapat berupa larutan asam, udara, air dan uap yang masing-masing mempunyai daya hantar listrik yang berbeda-beda. Penurunan mutu logam yang dimaksud adalah berkurangnya nilai logam baik dari segi ekonomi maupun teknik. Logam yang sudah menurun kwalitasnya bisa menimbulkan akibat yang lebih serius pada sifat fisik bahan. Disamping itu logam yang mengalami korosi juga berpenampilan kurang menarik sehingga memerlukan biaya perawatan yang mahal. Air merupakan pelarut yang istimewa sehingga biasanya sedikit maupun banyak mengandung zat-zat yang terlarut didalamnya. Korosi dalam air terbentuk karena penggabungan besidan oksigen didalam air. Kebanyakkan dari penggunaan logam di air laut terserang korosi, Laju korosi untuk baja lunak dalam lingkungan laut terjadi di daerah hempasan gelombang, karena di daerah itu banyak tedapat oksigen. Di daerah hempasan gelombang ini laju korosi dari logam bisa lebih cepat dibandingkan dengan logam yang terendam air seluruhnya. Penyebab korosi udara adalah air yang berwujud embun atau kabut akibat kelembaban yang relatif tinggi. Kabut atau embun bisa mendatangkan bahaya korosi karena bisa membasahi seluruh permukaan logam, termasuk permukaan yang tersembunyi. Lapisan-lapisan tipis air dari embun atau kabut tidak akan mengalir dan akan tetap disitu sampai menguap oleh hembusan angin atau meningkatnya temperatur [2][10].

\subsection{Laju Korosi}

Laju korosi sangat dipengaruhi oleh jumlah oksigen terlarut, semakin banyak oksigen yang terlarut maka laju korosi akan semakin cepat. Pada umumnya dengan meningkatnya temperatur maka laju korosi akan semakin cepat, dan sebaliknya laju korosi akan turun bila temperatur menurun. Asam merupakan larutan korosif yang sangat agresif untuk baja. Beberapa jenis material logam justru akan mengakibatkan kepasifan jika berada pada lingkungan asam. Kelembaban udara diatas $60 \%$ dan akan bertambah besar jika udara mengandung $\mathrm{SO}_{2}$. Konsentrasi elektrolit yang terlalu pekat akan menghambat laju korosi. Kecepatan aliran yang kuat akan mempercepat korosi erosi pada logam [10].

\subsection{Metode Kehilangan Berat}

Metode kehilangan berat adalah dengan mengukur kekurangan berat akibat korosi yang terjadi. Metode ini menggunakan jangka waktu penelitian hingga mendapatkan jumlah kehilangan akibat korosi yang terjadi. Mendapatkan kehilangan berat persatuan luas tergantung pada teknik pengukuran yang digunakan dan dinyatakan dalam satuan mils per year (mpy) dan besarnya laju korosi dinyatakan dengan persamaan (7) [2] :

$$
\mathrm{CR}(\mathrm{mpy})=\frac{\mathrm{K} \times W_{\text {loss }}}{\rho \times A \times T}
$$

dengan: $\mathrm{CR}=$ Laju korosi $(m p y) ; \mathrm{K}=$ Konstanta laju korosi; $\mathrm{W}=$ Selisih massa (gram); $\mathrm{T}$ = Waktu perendaman (jam); $\mathrm{A}=$ Luas permukaan $\left(\mathrm{cm}^{2}\right) ; \rho=$ Massa jenis $\left(\mathrm{gram} / \mathrm{cm}^{3}\right)$.

Efisiensi baja karbon mengindikasikan sejauh mana laju korosi diperlambat oleh kehadiran perlakuan pack carburizing. Efisiensi laju korosi dapat ditulis dalam persamaan berikut [2] :

$\eta(\%)=\left(\frac{\text { CRtanpa perlakuan }- \text { CRperlakuan })}{\text { CRtappaperakun }} \times 100 \%\right.$ 
dengan: $\eta=$ Efisiensi laju korosi (\%); CR = Laju korosi (mpy)

\subsection{Dimensi Spesimen}

Baja AISI 1045 dengan ukuran diameter 16 $\mathrm{mm}$ dan panjang $25 \mathrm{~mm}$, dipotong sesuai dengan ukuran spesimen uji, ditunjukkan pada gambar 1 .

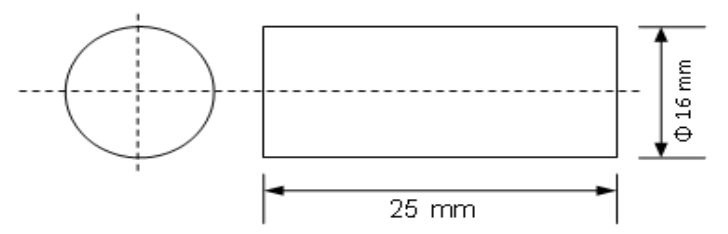

Gambar 1. Ukuran Spesimen uji

\subsection{Proses Penelitian}

Tempat pack carburizing (wadah) berfungsi untuk menempatkan dan mencampur media carburizing pada saat proses pack carburizing. Bentuk dari wadah pack carburizing berupa tabung yang terbuat dari pipa baja dengan ukuran diameter $50 \mathrm{~mm}$, panjang $100 \mathrm{~mm}$, dan tebal 4 $\mathrm{mm}$ pada Gambar 2(a)

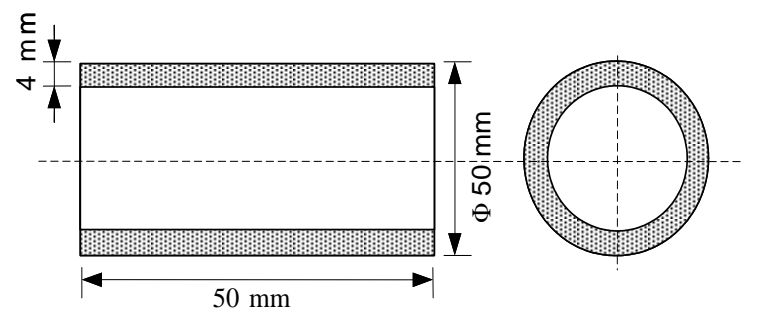

(a)

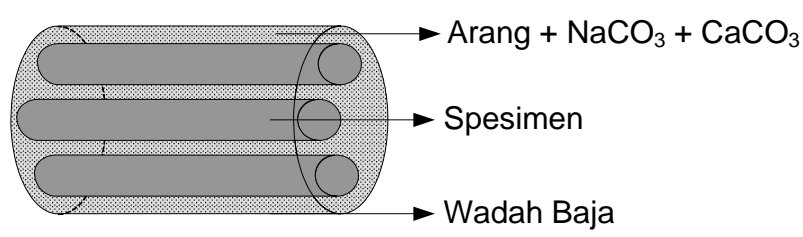

(b)

Gambar 2. (a) Dimensi wadah pack carburizing (b) Spesimen dalam wadah

Pada wadah dimasukkan benda uji dan campurkan media carburasi kedalam wadah baja dimana penempatan benda kerja yang satu dengan yang lain harus mempunyai jarak yang sama, kemudian wadah baja ditutup rapat (kedap udara) pada gambar 2(b). Kemudian dalam dapur pemanas wadah dimasukkan kedalam dapur pemanas dan dipanaskan pada temperatur $750^{\circ} \mathrm{C}$, $850^{\circ} \mathrm{C}$, dan $950^{\circ} \mathrm{C}$ dengan lama waktu penahanan 1 jam ditunjukan pada gambar 3

Proses pengkorosian yang dilakukan pada penelitian ini adalah dengan jalan merendam spesimen uji kedalam media kerja yang berupa air tawar, air laut dan diusahakan tidak terjadi kontak dengan udara luar pada gambar 4(a) dan (b). Sedangkan untuk pengkorosian dengan media kerja udara, spesimen dibiarkan diudara terbuka.

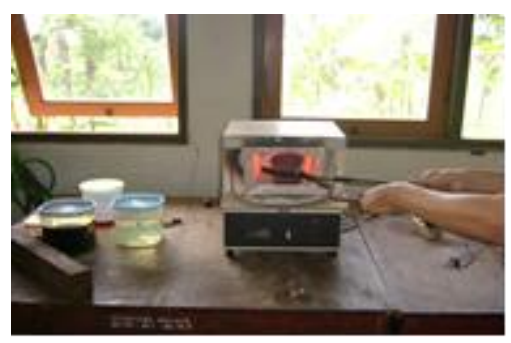

Gambar 3. Dapur Pemanas

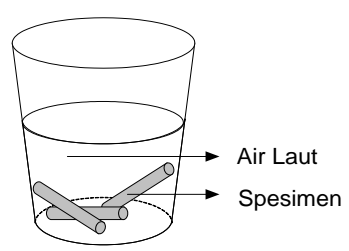

(a)

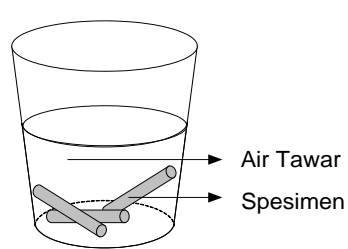

(b)
Gambar 4. Media korisif (a) air laut (b) air tawar

Setelah berjalan selama 30 hari, spesimen diangkat dari media pengkorosi kemudian dikeringkan. Spesimen ditimbang kembali.

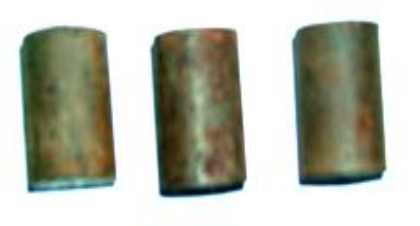

\section{Gambar 5. Spesimen setelah perlakuan pack carburizing dan media korosif}

\section{Hasil dan Pembahasan}

\subsection{Hasil Uji Laju Korosi}

Dalam penelitian ini diperoleh data proses pengkorosian pada media air, air laut dan udara, yaitu data pengurangan berat, laju korosi dan efisiensi korosi, seperti ditunjukkan masing-masing pada Tabel 1, 2 dan 3.

Pada Tabel 1 ditunjukkan bahwa dari proses tanpa pack carburizing maupun dengan pack carburizing dengan perlakuan temperatur memberikan efek pengurangan berat dan begitu juga laju korosi yang terbentuk semakin berkurang atau menurun (Tabel 2). Hal ini dapat disimpulkan bahwa efek temperatur proses pack carburizing berpengaruh secara signifikan. Terlihat juga dari perbedaan media korosi nilai laju korosi semakin meningkat dari media korosi udara, air tawar serta air laut 
Tabel 1. Pengurangan berat sampel selama proses korosi 30 hari (720 jam).

\begin{tabular}{ccccc}
\hline \multirow{2}{*}{ Media Korosi } & \multicolumn{4}{c}{ Pengurangan berat (gr) } \\
& TP & $750^{\circ} \mathrm{C}$ & $850^{\circ} \mathrm{C}$ & $950^{\circ} \mathrm{C}$ \\
\hline Udara & 0,07760 & 0,03016 & 0,02233 & 0,01846 \\
Air Tawar & 0,08336 & 0,05643 & 0,03846 & 0,02863 \\
Air Laut & 0,09345 & 0,06627 & 0,05652 & 0,04614 \\
\hline TP = tanpa pack carburizing & & &
\end{tabular}

Tabel 2. Laju korosi

\begin{tabular}{ccccc}
\hline \multirow{2}{*}{ Media Korosi } & \multicolumn{4}{c}{ Laju Korosi (mpy) } \\
& TP & $750^{\circ} \mathrm{C}$ & $850^{\circ} \mathrm{C}$ & $950^{\circ} \mathrm{C}$ \\
\hline Udara & 5,1606 & 2,0057 & 1,4850 & 1,2276 \\
Air Tawar & 5,5437 & 3,7528 & 2,5577 & 1,9040 \\
Air Laut & 6,2147 & 4,4072 & 3,7588 & 3,0685 \\
\hline
\end{tabular}

Tabel 3. Effisiensi laju korosi

\begin{tabular}{cccc}
\hline \multirow{2}{*}{ Media Korosi } & \multicolumn{3}{c}{ Effisiensi laju korosi (\%) } \\
& $750^{\circ} \mathrm{C}$ & $850^{\circ} \mathrm{C}$ & $950^{\circ} \mathrm{C}$ \\
\hline Udara & 61,35 & 71,22 & 76,21 \\
Air Tawar & 32,31 & 53,86 & 65,65 \\
Air Laut & 29,09 & 38,09 & 50,63 \\
\hline
\end{tabular}

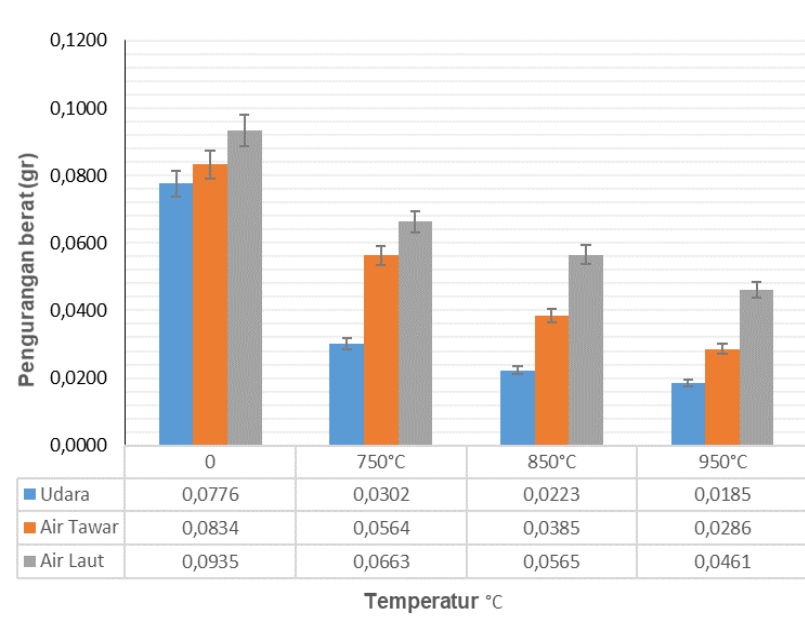

Gambar 6. Hubungan temperatur pack carburizing dengan pengurangan berat baja AISI 1045

Gambar 6 menunjukkan hasil pck carburizing dan media korosif terhadap pengurangan berat baja AISI 1045 akibat dari proses terbentuknya korosi. Pengaruh temperatur pack carburizing yang diberikan pada material baja AISI 1045 dari tanpa perlakuan sampai dikenai perlakuan mulai temperatur: $0^{\circ} \mathrm{C}, 750^{\circ} \mathrm{C}, 850^{\circ} \mathrm{C}$, dan $950^{\circ} \mathrm{C}$ dengan media korisif selama waktu 30 hari, terjadi pengurangan berat semakin kecil. Dapat ditunjukan dari hasil pengujian pada temperatur $750^{\circ} \mathrm{C}, 850^{\circ} \mathrm{C}$, dan $950^{\circ} \mathrm{C}$, berturut-turut sebesar $(0,03016 \mathrm{gr}, 0,02233 \mathrm{gr}$ dan $0,01846 \mathrm{gr}$ pada media Udara); $(0,05643 \mathrm{gr}, 0,03846 \mathrm{gr}$ dan $0,02863 \mathrm{gr}$ pada media air tawar); $(0,05643 \mathrm{gr}$, $0,03846 \mathrm{gr}$ dan $0,02863 \mathrm{gr}$ pada media air laut).
Hal ini disebabkan karena unsur karbon terserap lebih tebal pada bagian permukaan baja AISI 1045 yang sudah diberikan perlakuan pack carburizing. Pada setiap perlakuan media korosif dari media udara, media air tawar serta media air laut masing - masing memberikan peningkatan hasil pengurangan berat disetiap perlakuan temperatur pack carburizing [10].

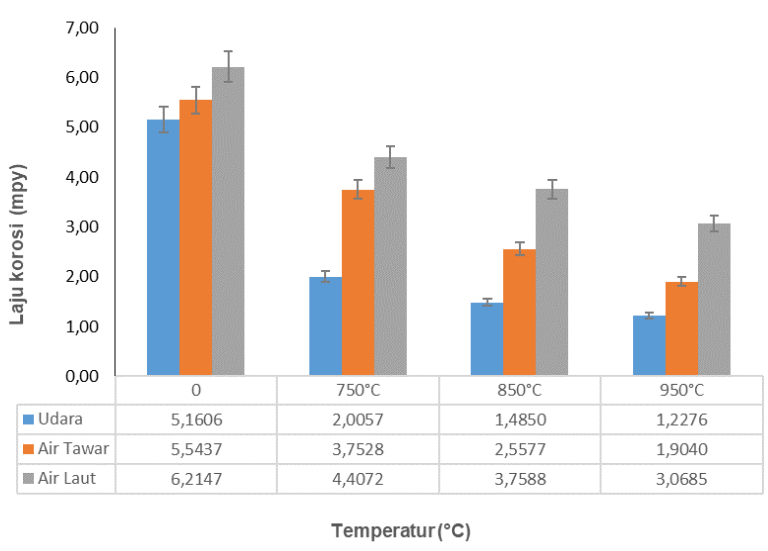

Gambar 7. Hubungan temperatur pack carburizing dengan laju korosi baja AISI 1045

Gambar 7 memperlihatkan hasil laju korosi dengan perlakuan temperatur pack carburizing dan media korosif pada baja AISI 1045. Pengaruh temperatur pack carburizing yang diberikan pada material baja AISI 1045, tanpa perlakuan temperatur $0^{\circ} \mathrm{C}$ dan perlakuan temperatur $750^{\circ} \mathrm{C}$, $850^{\circ} \mathrm{C}$, dan $950^{\circ} \mathrm{C}$ dengan media korisif selama waktu 30 hari, terjadi penurunan laju korosi semakin kecil. Dapat ditunjukan dari hasil pengujian pada temperatur $750^{\circ} \mathrm{C}, 850^{\circ} \mathrm{C}$, dan $950^{\circ} \mathrm{C}$, berturut-turut sebesar $(2,00573 \mathrm{mpy}$, 1,48501 mpy dan 1,22765 mpy pada media Udara); (3,75277 mpy, 2,55771 mpy dan 1,90398 mpy pada media air tawar); (4,40716 mpy, 3,75875 mpy dan 3,06845 mpy pada media air laut). Hal ini disebabkan karena unsur karbon terserap lebih tebal pada bagian permukaan baja yang sudah diberikan perlakuan pack carburizing shingga menjadi kuat dan keras yang dapat menghambat terbentuknya laku korosi. Pada setiap perlakuan media korosif dari media udara, media air tawar serta media air laut masingmasing memberikan peningkatan hasil laju korosi disetiap perlakuan temperatur pack carburizing. $\mathrm{Hal}$ ini dikerenakan media korosif udara memberikan laju korosi yang rendah sedangkan media air laut memberikan laju korosi tinggi [10, $11]$.

\subsection{Hasil Uji Efisiensi Korosi}

Hasil uji efisiensi korosi dari perlakuan temperatur pack carburizing dan media korosif pada baja AISI 1045 dapat dilihat pada gambar 8 . Gambar ini memperlihatkan hubungan media korosif dengan efisiensi laju korosi pada baja AISI 
1045 yang telah dikenai temperatur pack carburizing serta media korosif. Perbandingan laju korosi yang dikenai perlakuan temperatur pack carburizing dan tanpa perlakuan pack carburizing akan didapatkan efisiensi dari laju korosi.

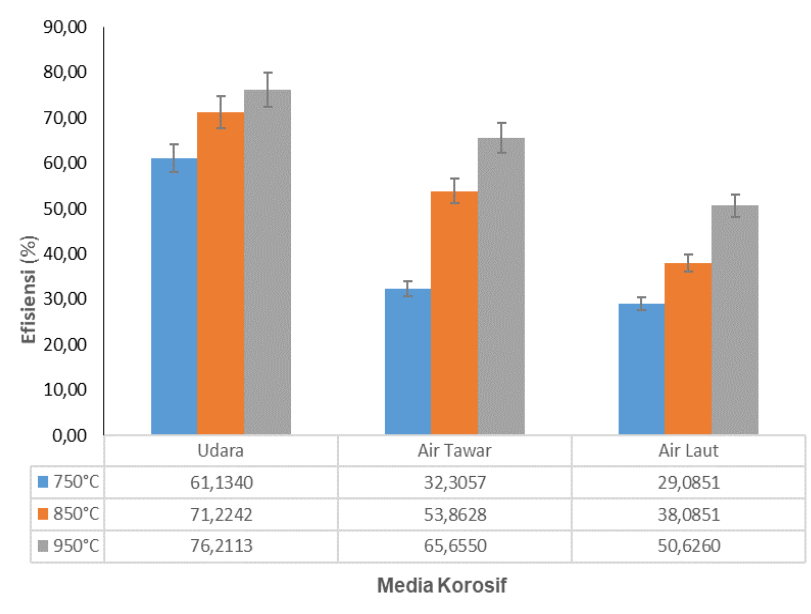

Gambar 8. Hubungan efisiensi, suhu karbonisasi dan media korosi

Pada Gambar 8 didapat bahwa efisiensi dari temperatur pack carburizing terus meningkat, dari $61,1340 \%$ saat penambahan temperatur $750^{\circ} \mathrm{C}$, kemudian efisiensi meningkat menjadi $71,2242 \%$ pada penambahan temperatur $850^{\circ} \mathrm{C}$, selanjutnya efisiensi meningkat maksimum menjadi $76,2113 \%$ pada saat penambahan temperatur $950^{\circ} \mathrm{C}$. Hal ini berarti temperatur pack carburizing berfungsi memperlambat terbentuknya korosi pada lingkungan udara. Begitu juga pada lingkungan air tawar temperatur pack carburizing juga memperlambat terjadinya korosi. Seperti ditunjukan dari $32,3057 \%$ saat penambahan temperatur $750^{\circ} \mathrm{C}$, kemudian efisiensi meningkat menjadi $53,8628 \%$ pada penambahan temperatur $850^{\circ} \mathrm{C}$, serta efisiensi meningkat menjadi $65,6550 \%$ pada saat penambahan temperatur $950^{\circ} \mathrm{C}$. Pada lingkungan korosif air laut menunjukan nilai peningkatan dari $29,0851 \%$ saat penambahan temperatur $750^{\circ} \mathrm{C}$, kemudian efisiensi meningkat menjadi $38,0851 \%$ pada penambahan temperatur $850^{\circ} \mathrm{C}$, kemudian efisiensi meningkat menjadi $50,6260 \%$ pada saat penambahan temperatur $950^{\circ} \mathrm{C}$. Jadi dapat tarik kesimpulkan bahwa temperatur pack carburizing dapat berfungsi memperlambat terbentuknya korosi pada lingkungan udara, air tawar dan juga air laut.

\section{Simpulan}

1. Perlakuan pack carburizing pada spesimen uji sangat berpengaruh terhadap laju korosi, yaitu laju korosinya lebih lambat dibandingkan dengan spesimen uji tanpa perlakuan pack carburizing.
2. Tingkat laju korosi spesimen uji yang melalui proses pack carburizing pada temperatur $750^{\circ} \mathrm{C}$ adalah paling cepat, dan laju korosinya menurun seiring dengan naiknya temperatur pack carburizing.

3. Media pengkorosian yang berupa udara, air tawar dan air laut sangat berpengaruh terhadap efisiensi laju korosi spesimen uji.

\section{Ucapan Terima Kasih}

Penulis mengucapkan terima kasih kepada Prodi Teknik Mesin, Fakultas Teknik Universitas Udayana, Kepala Laboratorium Metalurgi dan Laboratorium Proses Produksi serta Laboratorium Fenomena Jurusan Teknik Mesin Universitas Udayana, Kepala Laboratorium Metalurgi Institut Teknologi (ITN) Malang dan Kepala Laboratorium Metalurgi Jurusan Teknik Mesin Universitas Brawijaya Malang atas fasilatas yang diberikan.

\section{Daftar Pustaka}

[1] K. Trethewey and J. Chamberlain, Korosi. PT Gramedia Pustaka Utama, Jakarta, 1991.

[2] M. G. Fontana, Corrosion Engineering. Mc Graw Hill International Book Company, Singapura, 1967.

[3] K. Suarsana and I. N. Santhiarsa, Laju Korosi dengan Perubahan Besar Derajat Deformasi Plastis dan Media Pengkorosi Pada Material Baja Karbon, J. Ilm. Tek. Desain Mek., vol. 6, no. 3, pp. 290-304, 2017.

[4] D. Satria et al., Pengaruh Waktu Tahan Proses Pack Carburizing Baja AISI 3115 dengan Menggunakan Calcium Carbonat dan Batubara Sub Bituminous dan Mendapatkan Perlakuan Panas Quenching Media Pendingin Air, Rotasi, vol. 21, no. 2, p. 88, 2019, doi: 10.14710/rotasi.21.2.88-95.

[5] H. Hafni, Pengaruh Waktu Tahan Proses Pack Carburizing pada Baja Karbon Rendah dengan Menggunakan Calcium Carbonat dan Arang Tempurung Kelapa, Di Tinjau Dari Kekerasan, J. Tek. Mesin, vol. 5, no. 2, 2015.

[6] Supomo and Heri, Buku Ajar Korosi, Jurusan Teknik Perkapalan FTK. ITS Surabaya, 2003.

[7] W. Callister, Material Science and Engineering an Introduction 7 edition. JohnWiley and Sons. Inc., 2007.

[8] Yunaidi, Perbandingan Laju Korosi Pada Baja Karbon Rendah dan Stainless Steel Seri 201, 304, dan 430 Dalam Media Nira, Mek. dan Sist. Termal, vol. 1, no. 1, pp. 1-6, 2016.

[9] F. O. Aramide, S. A. Ibitoye, I. O. Oladele, and J. O. Borode, Pack Carburization of Mild Steel, Using Pulverized Bone As Carburizer: Optimizing Process Parameters, Leonardo Electron. J. Pract. Technol., vol. 9, no. 16, pp. 1-12, 2010.

[10] D. Kurniawan, Pengaruh Temperatur Pack Carburizing dan Media Pengkorosi Terhadap Laju Korosi Baja Aisi 1045, in Thesis 
Research, Udayana University, 2006.

[11] A. Yudha Kurniawan Afandi, Irfan Syarif Arief, Analisa Laju Korosi pada Pelat Baja Karbon dengan Variasi Ketebalan Coating,"J. Tek. Its, vol. 4, no. 1, pp. 1-5, 2015.

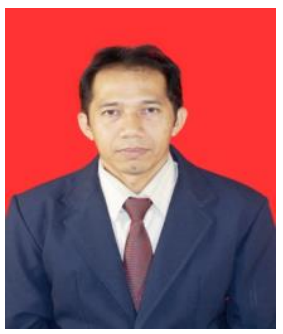

Kt. Suarsana menyelesaikan pendidikan S1 Teknik Mesin di Universitas Udayana pada tahun 1991. Judul skripsi Perancangan Mesin disiel sebagi pembangkit generator untuk penggerak Pompa. Pendidikan magister Teknik Mesin diselesaikan di ITS Surabaya pada tahun 2000 dengan area riset tentang Tesis Laju perambatan retak material AL 2024-T3 pada Amplitude Konstan.

Pada tahun 2014 menyelesaikan pendidikan doktoral di Universitas Brawijaya, Malng, Indonesia. Judul Disertasi Karakteristik Composite Matrik Aluminium Fine Powder Diperkuat SiC Whisker dan Alumina dengan Proses powder Metalurgi. Saat ini ia bekerja sebagai dosen di Jurusan Teknik Mesin Uinversitas Udayana. Bidang penelitian utama yang digeluti adalah Material maju, Composit, Korosi, dan Teknik Pelapisan. 